\title{
The Quest for Knowledge
}

\author{
Dan Manolescu (Corresponding author) \\ Freelance ESL Instructor and Award-Winning Author, New York, USA \\ Email: dan.manolescu@att.net
}

Received: $29 / 11 / 2021$

Accepted: 11/02/2021

Published: 01/03/2022

Volume: 3 Issue: 2

How to cite this paper: Manolescu, D. (2022). The Quest for Knowledge. Journal of Practical

Studies in Education, 3(2), 12-15

DOI: https://doi.org/10.46809/jpse.v3i2.44

This work is licensed under the Creative Commons Attribution International License (CC BY

4.0).http://creativecommons.org/licenses/by/4.0/

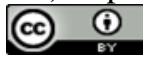

\begin{abstract}
This article is a quick inquiry into the quest for knowledge. Preliminary steps include the idea of light as it was promulgated during the period of Enlightenment, followed by the relevant role played by education, and then focusing on the passion for knowledge, as it is found in major literary and philosophical works. Curiosity and inquisitiveness are also mentioned because of their intrinsic value with references to classical as well as contemporary approaches. Throughout history, knowledge has been treated not only as quintessential in its multiple uses, but also prevalent because it deepened and broadened our core connection with the outside world. Famous dramatists are part of our discussion, starting with Christopher Marlowe, who condemns his Faustus and continuing with Goethe, the German poet who argues that Faustus should be forgiven because he was in the pursuit of knowledge. Along the same lines, a new approach to learning in our quest for knowledge was introduced by Peter Senge. What we do when we really learn something new is, according to Senge, what makes us human. In conclusion, we might say that the quest for knowledge brings us joy and that the passion for knowledge is an inborn trait that makes us who we are. We learn something every day and we are never satisfied because we always want to know more.
\end{abstract}

Keywords: Knowledge, Curiosity, Inquisitiveness, Learning, Imagination

\section{Introduction}

The Light in the period of Enlightenment (1601-1800) had its most important sources focus on methods of discovering truth based on rational and empirical methods as they were introduced by scientific revolution.

Famous personalities across the globe, like Voltaire, Montesquieu, Diderot, Rousseau in France, David Hume and Adam Smith in Scotland, Immanuel Kant in Germany, and the American statesman Thomas Jefferson, were some of the thinkers who proposed that human reasoning could discover truths about the world, religion, and politics and thus lead us to a better life overall. For them, enlightenment celebrated the new concept of reason.

According to Rohr "Light is not so much what you directly see as that by which you see everything else." (Rohr, 2019, p. 14) In other words, light is perceived not only as the opposite of darkness, but also because of its intrinsic value in revealing what we can do with light. The same goes for knowledge. It's not only what you learn, but what you can do with your knowledge. We strive so hard to find knowledge that we simply forget that in the process of learning we utilize it as a goal, when in fact this concept engages our heart, our body, and our awareness of the physical world around us, especially our communication with ourselves and with our peers. Knowledge, once acquired, deepens and broadens our core connection with the outside world, it goes beyond the mental comprehension of words and ideas, and has larger implications beyond our imagination. 


\section{Discussion}

We look at books and written or oral information as a solid body of coherent enlightenment, but that also leads us to a more social, historical, and revolutionary sense of ourselves. Knowledge at its essential core is not only a worthy beginning, but it is also like a flame which later on will become a blaze. Books attract us because they stir our imagination, and in doing so, they motivate us to find meaning in our lives. According to Wohlleben (2019), we can learn a lot simply by looking at nature. "Nature is like the mechanism of an enormous clock." The knowledge we find in books will teach us that everything is beautifully arranged and interconnected. To validate his assessment, the author resorts to a personal story:

I was about five years old and on vacation visiting my grandparents in Wurzburg when my grandfather gave me an old clock. The first thing I did was take the clock apart, because I just couldn't wait to find out how it worked. Even though I was convinced that I knew how to put it back together in working order, I couldn't do it. After all, I was just a young child. After I rebuilt it, there were a few cogs left over - and a grandfather who was not in the best of moods. In the wild, wolves play the role of such cogs. If we eradicate them, not lonely do the enemies of sheep and cattle ranchers disappear, but the finely tuned mechanism of nature also begins to run differently, so differently that rivers change course and many local bird species die out. (Wohlleben, 2019, p. 2)

In the classroom or online, a good teacher will play the role of such cogs. Technology provides an added touch, but it is the knowledge of a good teacher that entices the fascinating interplay between student and student, and empowers them to question, discover, and communicate with each other.

Education starts with questions and teachers are the ones who know that the whole process of learning is based on the exchange of information between the instructors and their students. In many cases, the quest for knowledge entices the reader to question himself and his own endeavor.

The passion and the quest for knowledge start with curiosity. I must admit I always asked questions when I was a student. I am not sure whether my teachers and my colleagues liked what I said or how I said it, but I thought it was necessary for me to say something. Whether it was a yes/no question, or whether I wanted some new information, I just went on and on until I thought I got the answer I wanted to hear.

Teachers do the same. They ask questions all the time. If you really want to get your students involved in your classes, you, the instructor, or the teacher, or the professor, should guide your conversations based on questions. This will give your students a chance to practice what they already know. If we empower them and teach them to be inquisitive, very soon they will find the process extremely useful. Students should do the same - ask questions all the time.

St. Augustine was known to be an example of a thinker who liked to be inquisitive. "Augustine thinks in questions," said Karl Jaspers (1883-1969). Working late into the night, sometimes alone, at other times surrounded by stenographers, St. Augustine was a tireless seeker and was never satisfied. He dictated and preached several times a week, and that frequency led him to compose an estimated number of eight thousand sermons, which made him not only prolific, but also extremely widely known for his views. According to his own estimate, he wrote approximately ninety-three books. His dynamic character and his restlessness are obvious when he describes the human urgency toward truth:

The impulse present in our seeking goes beyond the seeker, and hovers as it were, unable to rest in any other goal until what is sought has been found and the seeker is united with it. This impulse, or search, does not seem to be love, which we have for known things, since it is an effort toward the unknown. Yet it has a quality cognate to love. It can be called an act of will, for the seeker wills to find, and if something knowable is being sought, then the seeker has a will to know. If that seeking is urgent and focused, it is called studious - our term for those wanting to master knowledge. So an impulse of some kind precedes the mind's generative act, and through this will to seek and find knowledge, the knowledge itself comes to birth. (Trin 0.18) (Quoted in Garry Wills, Saint Augustine, 2005, p. xiii)

My curiosity helped me in many ways, although at times it got me into trouble. Not all teachers like to be interrupted or questioned. Not all the students are comfortable when their teachers pose questions that might confuse the audience. However, we should follow our instincts and come up with questions because, in my opinion, that is the best way to discover knowledge. Since education starts with questions, by being inquisitive, we discover new information. Reading is just one way books can encourage and empower readers to go on a journey of discovery.

According to Grazer \& Fishman (2015), reading, for those who want to spend their lives with books, will provide answers because we are seeking-information creatures and therefore curious.

Psychologists define curiosity as "wanting to know." That's it. And that definition squares with our own commonsense feeling. "Wanting to know," of course, means seeking out the information. Curiosity starts out as an impulse, an urge, but it pops out into the world a something more active, more searching: a question.

(Grazer \& Fishman, 2015, p. 10)

Whether we want to know ourselves, or whether we tend to find joy in discovering new ideas and new things in the outside world, the desire to know becomes irresistible and turns into passion.

\subsection{The passion for Knowledge}

Since the dawn of times, we have been searching for new things, new ideas, new concepts, new everything. The quest for beauty, knowledge, and power can well be what Christopher Marlowe (1564-1593) exalted in his writing:

Our souls, whose faculties can comprehend 
The wondrous architecture of the world,

And measure every wandering planet's course,

Still climbing after knowledge infinite,

And always moving as the restless spheres,

Will us to wear ourselves, and never rest

Until we reach the ripest fruit of all.

(Marlowe, Tamburlaine the Great, Part I, Act II, vii)

The eloquence and the author's choice of words may have been behind the success of the play, once considered among the front-runners of the Elizabethan stage. The audience reciprocated their reception by praising him so much that he had to raise the bar and around 1588 produced The Tragical History of Doctor Faustus. The myth of Faustus was not new to his contemporaries, and Marlowe himself was well aware that "the joy of understanding is a sad joy," and that "much knowledge is much grief." In his view, Faustus was a learned man, a famous physician in Wittenberg, who debated with himself the limits of knowledge, but also had dreams of magic that would make him extremely powerful:

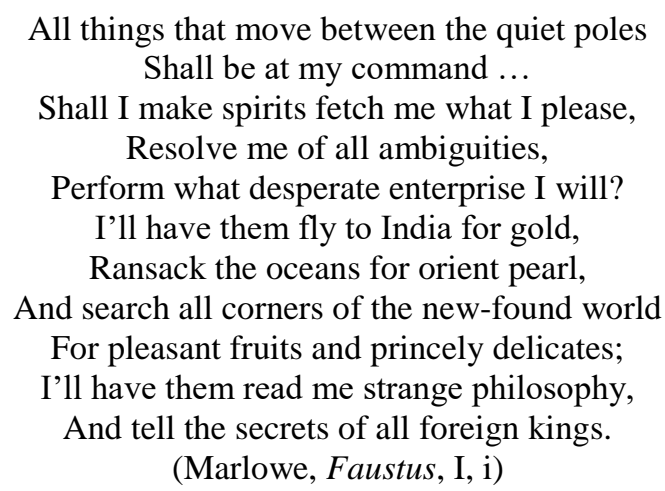

From Marlowe we can now segue to Goethe (1749-1832), who made Faustus assume the role of God in his quest for knowledge. Goethe's Faust is still the play with the largest audience numbers on German-language stages, with a small but significant change in the end when Faust is not damned for signing the pact with Lucifer because, as the German poet intended to emphasize, as the creator of a new world, Faustus was in the pursuit of knowledge and envisioned a new paradise and was well aware of his possession of the knowledge he has sought:

Yes, I am utterly devoted to this idea,

This is wisdom's last conclusion:

Only he earns life and liberty,

Who daily has to conquer them.

(Goethe, Faust, 11573-6)

But did Faust find it? Did he find wisdom? If we look carefully in the melody of speech and the lucid verse flow, Faust found himself in a situation he describes as a circulus vitiosus, for the lack of better words, a condition of infinitely striving after, but never reaching the goal.

\subsection{The Quest for Knowledge Brings Us Joy}

The passion for knowledge is an inborn trait that makes us who we are. We learn something every day and we are never satisfied because we always want to know more. Peter M. Senge (1990) introduced his new approach to learning in our quest for knowledge in his book entitled The Fifth Discipline - The Art and Practice of the Learning Organization. According to the author, we need to look deeper into the concept of learning. Senge started his groundbreaking search by looking at the word metanoia, which, he says, has a rich history. "For the Greeks, it meant a fundamental shift or change, or more literally transcendence (meta - above or beyond, as in metaphysics) of mind (noia, from the root nous, of mind). In the early (Gnostic) Christian tradition, it took on a special meaning of awakening shared intuition and direct knowing of the highest, of God. [....] To grasp the meaning of metanoia is to grasp the deeper meaning of learning, for learning also involves a fundamental movement of mind.” (Senge, 1990, p. 13)

What we do when we really learn something new is, according to Senge, what makes us human. Learning is thus perceived as a powerful tool that we, humans, can use to slake our thirst for knowledge. The desire to know is universal and encompasses all walks of life, all cultures, and all ages. We don't know how it started or how it developed, but we certainly know it grows by what it feeds on and by the unique capacity to create and re-create.

Through learning we re-create ourselves. Through learning we become able to do something we never were able to do. Through learning we re-perceive the world and our relationship to it. Through learning we extend our capacity to create, to be part of the generative process of life. (p. 14)

In order to create, we need to communicate our knowledge in a language that can cross boundaries and centuries. If knowledge comes from learning, if it is based on observation and experiment, knowledge grows because it is driven by research. In other words, we build our body of knowledge when we ask questions and then do our best to find answers. 


\section{Conclusion}

Some people say that if you are a hammer, everything looks like a nail. Something similar happens when teachers find an interesting, challenging, or motivating piece of information that might become a good source of instruction. We automatically or instinctively turn this into a good topic for the next day. In doing so, we devise this competitive game with ourselves and our students. And this is what makes knowledge so desirable and so relevant - we need to reach out to share our knowledge.

\section{References}

Goethe, J. W. v. (2015). Faust: Parts I and II. United States: CreateSpace Independent Publishing Platform.

Grazer, B \& Fishman, C. (2015). A Curious Mind. The Secret to a Bigger Life. New York: Simon \& Schuster.

Jaspers, K. (2017). Way to Wisdom: An Introduction to Philosophy (Classic Reprint). United Kingdom: 1kg Limited.

Marlowe, C. (1967). Tamburlaine the Great. Lincoln: University of Nebraska Press.

Marlowe, C. (2019). The Tragical History of Doctor Faustus. Germany: Books on Demand.

Rohr, R. (2019). The Universal Christ. New York: Convergent.

Senge, P. M. (1990) The Fifth Discipline. The Art and Practice of the Learning Organization. New York: Doubleday.

Wills, G. (2005). Saint Augustine. Penguin Books.

Wohlleben, P. (2019). The Secret Wisdom of Nature. Trees, Animals, and the Extraordinary Balance of All Living Things. Stories from Science and Observation. Munich: Ludwig Verlag. 